\title{
Pengaruh Faktor Internal dan Eksternal Terhadap Tingkat Kesehatan Bank
}

\author{
Liliani Wijaya dan Nuryasman MN \\ Fakultas Ekonomi Universitas Tarumanagara, DKI Jakarta \\ lilianiwijaya96@gmail.com dan nuryasmanmn@gmail.com
}

\begin{abstract}
This search has a purpose to provide emperical evidence about factors that affect health of banks. The examine factors internal on this research are CAMELS and the examine factor external on this research is Gross Domestic Product (GDP). The sample consist of 29 banks.Object of this study is the commercial banks operating in Indonesia in 2012-2015. Determination of sampling technique using purposive sampling method in which the sample is taken with certain criteria. Because the data is used are secondary datawith a quantitative approach, it is necessary to determine the accuracy of the model on some assumption of hypothesis testing using Stata tools. The result showed a partial variable NPL and IER are significant effect on the level of health. While variable CAR, NPM, ROA, LDR, and GDP insignificant effect of the health of the bank. During the period 2012-2015 there were more than 50\% showed a stable bank or banks that are in the tittle of "Fit". Although they are some banks that have increased and decreased to earn the tittle of "unhealthy" for 4 periods.
\end{abstract}

Keywords: Camels, Bank Ratio , Analysis of Financial Performance

\begin{abstract}
Abstrak: Penelitian ini bertujuan untuk memberikan bukti empiris tentang faktor-faktor yang mempengaruhi kesehatan bank. Variabel yang digunakan faktor internal dalam penelitian ini adalah CAMELS dan faktor eksternal pada penelitian ini adalah Produk Domestik Bruto (PDB). Sampel terdiri dari 29 bank.Obyek dari penelitian ini adalah bankbank umum yang beroperasi di Indonesia pada 2012-2015. Penentuan teknik pengambilan sampel menggunakan metode purposive sampling dimana sampel diambil dengan kriteria tertentu. Karena data yang digunakan adalah data sekunder dengan pendekatan kuantitatif, perlu untuk menentukan ketepatan model pada beberapa asumsi pengujian hipotesis dengan menggunakan alat Stata. Hasilnya menujukan variabel NPL dan IER yang berpengaruh signifikan terhadap tingkat kesehatan. Sementara variabel CAR, NPM, ROA, LDR, dan PDB efek signifikan dari kesehatan bank. Selama periode 2012-2015 ada lebih dari 50\% menunjukkan bank stabil atau bank yang berada di titik dari "Fit". Meskipun mereka beberapa bank yang mengalami peningkatan dan penurunan untuk mendapatkan judul dari "tidak sehat" untuk 4 periode.
\end{abstract}

Kata Kunci : Camels, Rasio Bank, Analisis Kinerja Keuangan

\section{PENDAHULUAN}

Indonesia sebagai salah satu negara sedang berkembang dituntut untuk senantiasa meningkatkan pertumbuhan ekonomi masyarakatnya melalui pembinaan pilar ekonomi yangdianggap mampu menopang dan meningkatkan kesejahteraan masyarakat secara adil dan merata. 
Kasmir (2008:25) menjelaskan bahwa bank adalah lembaga keuangan yang kegiatan utamanya menerima simpanan giro, tabungan dan deposito, kemudian bank juga dikenal sebagai temoat untuk meminjam uang (kredit) bagi masyarakat yang membutuhkannya.

Menurut Undang-Undang RI Nomor 04 Tahun 2008 tentang perbankan. Perbankan adalah segala sesuatu yang menyangkut tentang bank, mencangkup kelembagaan, kegiatan usaha, serta cara dan proses dalam melaksanakan kegiatan usahanya. Sedangkan bank adalah badan usaha yang menghimpun dana dari masyarakat dalam bentuk simpanan dan menyalurkannya kepada masyarakat dalam bentuk kredit dan bentuk-bentuk lainnya dalam rangka meningkatkan taraf hidup rakyat banyak. Dari pengertian tersebut dapat dijelaskan bahwa bank adalah perusahaan yang bergerak dalam bidang keuangan, dan aktivitasnya pasti berhubungan dengan masalah keuangan.

Fungsi dari bank menurut Totok Budisantoso (2006:9) adalah menghimpun dana dari masyarakat dan menyalurkannya kembali kepada masyarakuat, untuk itu berabagai tujuan atau sebaagai financial intermdiary. Dengan menjalankan fungsi-fungsi tersebut diharapkan dapat memberikan pelayanan yang baik kepada masyarakat serta bermanfaat bagi perekonomian secara keseluruhan.Untuk dapat menjalankan fungsinya dengan baik, bank harus mempunyai modal yang cukup, menjaga kualitas asetnya dengan baik, dikelola dengan baik dan dioperasikan berdasarkan prinsip kehati-hatian, menghasilkan keuntungan yang cukup untuk mempertahankan kelangsungan usahanya, serta memelihara likuiditasnya sehingga dapat memenuhi kewajibannya setiap saat. Selain itu, suatu bank harus senantiasa memenuhi berbagai ketentuan dan aturan yang telah ditetapkan, yang pada dasarnya berupa berbagai ketentuan yang mengacu pada prinsip-prinsip kehati-hatian di bidang perbankan.

Penilaian tingkat kesehatan bank di Indonesia sampai saat ini secara garis besar didasarkan pada faktor CAMEL (Capital, Assets Quality, Management, Earning, dan Liquidity). Saat ini BI tengah mempersiapkan penyempurnaan sistem penilaian bank yang baru, yang memperhitungkan sensitivity to market risk atau risiko pasar yang diatur dalam Peraturan Bank Indonesia Nomor 9/1/PBI/2007 Tentang Sistem Penilaian Tingkat Kesehatan Bank Umum. Dengan demikian faktor-faktor yang diperhitungkan dalam system baru ini nantinya adalah CAMELS. Keenam faktor tersebut memang merupakan faktor yang menentukan kondisi suatu bank. Apabila suatu bank mengalami permasalahan pada salah satu faktor tersebut (apalagi apabila suatu bank mengalami permasalahan yang menyangkut lebih dari satu faktor tersebut), maka bank tersebut akan mengalami kesulitan. CAMEL menurut Luciana dan Winny dalam Henita (2007:9) adalah aspek yang paling banyak berpenagruh terhadap kondisi keuangan bank, yang mempengaruhi pula tingkat kesehatan bank. CAMELS merupakan tolak yang menjadi objek pemerikasnan bank yang dilakukan oleh pengawas bank.

Dalam hal ini penulis ingin menganalisis kesehatan perusahaan pada sektor perbakan yang terdaftar dalam Bursa Efek Indonesia dengan melakukan analisis faktor internal dilihat dari CAMELSdan faktor eksternal dilihat dari GDP untuk dapat diketahui kriteria kesehatan suatu bank yaitu sehat, cukup sehat, kurang sehat, dan tidak sehat. Dari hasil penilaian tersebut nantinya, bank dapat mengambil kebijakan untuk kinerja bank dimasa yang akan datang. Jika dari hasil penilaian bank dinyatakan sehat maka bank harus mempertahankan tingkat kesehatannya, tetapi jika hasilnya bank dinyatakan tidak sehat maka bank harus meninggatkan tingkat kesehatannya. 


\section{KAJIAN TEORI}

Analisis CAMELS. Analisis CAMELS digunakan untuk mengevaluasi linerja keuangan bank umum di Indonesia.hal ini diatur dalam peraturan Bank Indonesia Nomor 6/10/PBI/2004 perihal sistem penilaian Tingkat Kesehatan Bank Umum.

Kesehatan Bank. Kesehatan Bank Menurut Kasmir (2008:41) adalah Tingkat kesehatan bank dapat diartikan sebagai kemampuan suatu bank dapat diartikan sebagai kemampuan suatu bank untuk melakukan kegiatan operasional perbankan secara normal dan mampu memenuhi semua kewajibannya dengan baik dengan cara-cara yang sesuai dengan peraturan perbankan yang berlaku.

\section{Penilaian Kesehatan Bank}

Tabel 1. Nilai Kredit Tingkat Kesehatan Bank

\begin{tabular}{cc}
\hline Nilai Kredit & Predikat \\
\hline $81-100$ & Sehat \\
$66-81$ & Cukup Sehat \\
$51-66$ & Kurang Sehat \\
$0-51$ & Tidak Sehat \\
\hline
\end{tabular}

Sumber: Surat Keputusan Direktur Bank Indonesia Nomor 6/23/DPNP tanggal $31 \mathrm{Mei}$ 2004

Penilaian tingkat kesehatan bank sejak April 2004 mengalami perubahan dengan dikeluarkannya Peraturan Bank Indonesi Nomor 6/10/PBI/2004 tanggal 12 April 2004 memperhitungkan Sensitivity to Market Risk dalam memnentukan nilai kredit tingkat kesehatan bank (CAMELS Rating System), seperti di tunjukan dalam tabel

Tabel 2. Komposisi CAMELS Penentuan Nilai Kredit Tingkat Kesehatan Perbankan

\begin{tabular}{cc}
\hline Komponen & Komposisi \\
\hline Capital & $25 \%$ \\
Assets Quality & $30 \%$ \\
Management & $20 \%$ \\
Earnings & $10 \%$ \\
Liquidity & $10 \%$ \\
Sensitivity to Market Risk & $5 \%$ \\
\hline
\end{tabular}

Sumber : Peraturan Bank Indonesia Nomor 6/10/PBI/2004 Tanggal 12 April 2004

Tabel 3. Peringkat Komposisi Kesehatan Bank

\begin{tabular}{cl}
\hline $\begin{array}{c}\text { Peringkat Komposit } \\
(\mathrm{PK})\end{array}$ & \multicolumn{1}{c}{ Penjelasan } \\
\hline 1 & $\begin{array}{l}\text { mencerminkan kondisi Bank yang secaraumum sangat sehat } \\
\text { sehingga dinilai sangat mampu menghadapi pengaruh negatif yang } \\
\text { signifikan dari perubahan kondisi bisnis dan faktor eksternal }\end{array}$ \\
& $\begin{array}{l}\text { lainnya. } \\
\text { mencerminkan kondisi Bank yang secaraumum sehat sehingga } \\
\text { dinilai mampu menghadapi pengaruh negatif yang signifikan dari } \\
\text { perubahan kondisi bisnis dan faktor eksternal lainnya. }\end{array}$ \\
\hline
\end{tabular}


3

mencerminkan kondisi Bank yang secaraumum cukup sehat sehingga dinilai cukup mampu menghadapi pengaruh negatif yang signifikan dari perubahan kondisi bisnis dan faktor eksternal lainnya.

4 mencerminkan kondisi Bank yang secaraumum kurang sehat sehingga dinilai kurang mampu menghadapi pengaruh negatif yang signifikan dari perubahan kondisi bisnis dan faktor eksternal lainnya.

mencerminkan kondisi Bank yang secaraumum tidak sehat sehingga dinilai tidak mampu menghadapi pengaruh negatif yang signifikan dari perubahan kondisi bisnis dan faktor eksternal lainnya.

Sumber: Peraturan Bank Indonesia Nomor 13/1/PBI/2011 tanggal 5 Januari 2011

Kerangka Pemikiran dan Perumusan Hipotesis. Sebagai lembaga intermediasi, tugas utama perbankan secar aumum adalah menghimpun dana dan menyalurkan dana kepada masyarakat yang kekurangan dana untuk pembiayaan investasi. Faktor-faktor yang mempengaruhi kinerja bank disebut CAMELS. penelitian ini mencoba untuk menguji pengaruh faktor internal (CAMELS) yang diwakili dengan menggunakan indikator capital Adquecy Ratio (CAR) untuk menilai Capital, menilai aset dengan rasio Non Performing Loan (NPL), menilai manajemen dengan rasio Net Profit Margin (NPM), menilai earning dengan rasio Return On Asset (ROA), menilai liquidity dengan rasio loan deposit Ratio (LDR), menilai sensitivity to marketrisk dengan Interest Expense Ratio (IER) dan faktor eksternal yang diwakili dengan GDP terhadap kesehatan perbankan dari faktor internal dan faktor eksternal maka akan di dapat hasil analisis tingkat kesehatan bank dan nantinya akan didapat kesimpulan yang berupa bahwa bank tersebut sehat, cukup sehat, kurang sehat atau tidak sehat.

Penelitian ini mencoba merumuskan beberapa masalah seperti: (1) Apakah terdapat pengaruh Faktor Internal (CAMELS) terhadap tingkat kesehatan bank pada periode 2012-2015?; (2) Apakah terdapat pengaruh Faktor Eksternal (GDP perkapita) terhadap kesehatan bank?.

\section{METODE}

Populasi, Sampel dan Data. Penelitian ini menggunakan bank umum yang ada di Indonesia dan terdaftar di Bursa Efek Indonesia pada tahun 2012-2015.Teknik analisis data yang digunakan dalam penelitian ini adalah dengan menggunakan analisis pendekatan kuantitatif. Teknik penentuan sampling dalam penelitian ini dengan menggunakan metode purposive sampling yaitu dilakukan dengan kriteria tertentu sesuai dengan tujuan penelitian, dimana sampel yang digunakan apabila memenuhi kriteria sebagai berikut: (a) bank umum yang ada di Indonesia yang menyediakan data laporan keuangan secara lengkap sesuai variabel yang akan diteliti selama tahun 2012-2015; (b) Bank umum yang ada di Indonesia dan terdaftar di Bursa Efek Indonesia; (c) IPO bank di bawah 2012.

Laporan data keuangan bank diperoleh dari publikasi http://www.idx.co.id, PDB diperoleh dari publikasi www.worldbank.org/. 
Metode Analisis. Dalam penelitian ini metode analisis yang digunakan adalah model analisis regresi panel dataData Panel merupakan kombinasi dari data time series dan cross-section. Dengan mengakomodasi informasi baik yang terkait dengan variabel-variabel cross-section maupun time series, model yang mengabaikan variabel yang relevan.

Persamaan regresi data panel adalah sebagai berikut :

$$
\begin{aligned}
& \mathrm{Y}_{\text {it }}=\alpha+\beta_{1} \mathbf{X}_{1 \text { it }}+\beta_{2} \mathbf{X}_{2 \text { it }}+\beta_{3} \mathbf{X}_{3 i t}+\beta_{4} \text { ROA }_{4 i t}+\beta_{5} \mathbf{L D R}_{5 i t}+\beta_{6} \mathbf{I E R}_{6 \text { it }}+ \\
& \beta_{7} \mathbf{G D P}_{7 \text { it }}+\varepsilon_{\text {it }}
\end{aligned}
$$

Keterangan :

$\mathrm{Y}_{\text {it }}$ adalah Variabel Terikat $\mathrm{X}_{\mathrm{it}}$ adalah Variabel Bebas,$\alpha$ adalah konstanta, $\mathrm{i}$

adalah entitas ke-i $\mathrm{t}$ adalah periode ke-t $\beta_{\mathrm{i}}$ adalah koefisien regresi, ${ }^{\varepsilon}$ adalah eror

Pemilihan model. Model yang digunakan dalam analisis data panel pada penelitian ini terdiri dari tiga metode yang bisa digunakan untuk bekerja dengan data panel, sebagai berikut: (1) Pooled least Square (PLS). Mmengestimasi data panel dengan metode OLS; (2) Fixed Effect (FE). Menambahkan model dummy pada data panel; (3) Random Effect (RE). Memperhitungkan error dari data panel dengan metode least square.

\section{HASIL DAN PEMBAHASAN}

Tabel 1. Hasil Statistik Deskriptif

\begin{tabular}{lcccccccc}
\hline Var & TKS & CAR & NPL & NPM & ROA & LDR & IER & GDP \\
Stat & & & & & & & & \\
Mean & 66,83 & 16,66 & 1,43 & 10,41 & 1,398 & 84,79 & 5,80 & 3544,58 \\
Min. & 35 & 8,02 & 0 & $-82,45$ & $-7,63$ & 55,78 & 0,32 & 3346,5 \\
Max. & 85,51 & 27,26 & 5,45 & 33,53 & 4,46 & 113,3 & 11,9 & 3700,5 \\
Std. Dev & 11,365 & 3,240 & 1,261 & 15,264 & 1,849 & 10,136 & 2,095 & 135,827 \\
Obs. & 116 & 116 & 116 & 116 & 116 & 116 & 116 & 116 \\
\hline
\end{tabular}

Sumber: Data Diolah Stata 13

Pada tahun 2012-2015 rata-rata untuk variabel CAR adalah 16,66\% dengan standar deviasi 3,24\% sesuai dengan peraturan Surat Edaran Bank 14/37/DPNP bahwa bank yang dinyatakan termasuk sebagai bank yang sehat harus memiliki CAR minimum sebesar $8 \%$. rata-rata CAR dalam penelitian ini sebesar 16,66\% menujukan bahwa rata-rata bank tersebut tergolong sehat dan permodalan yang menunjukan kemampuan bank alam menyediakan dana untuk keperluan pengembangan usaha dan menampung kemungkinan resiko kerugian yang diakibatkan dalam opersional bank tergolong bagus, serta standar deviasi CAR menunjukan sebaran data dalam sampel lebih kecil dari mean CAR maka nilai rata-rata dapat digunakan sebagai representasi dari keseluruhan data. rata-rata. Nilai Minimum dari CAR adalah 8,02\% milik bank Pundi Indonesia pada tahun 2015 walaupun paling rendah dari 28 bank lainnya tetapi hal ini menunjukan nilai CAR masih terbilang cukup bagus, karena standar minimum menurut Surat Edaran Bank adalah 8\%. Untuk nilai maksimum CAR adalah 27,26\% pada tahun 2012 hal ini menunjukan bahwa pada tahun 2012 rasio CAR pada bank QNB kesawan terbilang paling baik dari semua bank lainnya. 
Nilai rata-rata NPL dari tahun 2012-2015 adalah 1,43\% menunjukan bahwa rata-rata bank tergolong bagus dan telah memenuhi kriteria karena menurut ketentuan Bank Indonesia batas maksimum nilai NPL adalah 5\% sedangkan standar deviasi dari NPL adalah 1,261menunjukan sebaran data dalam sampel lebih kecil dari mean NPL maka nilai rata-rata dapat digunakan sebagai representasi dari keseluruhan data dan nilai minimum adalah 0\% dimana NPL minimum terdapat pada bank CIMB Niaga pada tahu 2012 dan 2013 yang menunjukan bahwa NPL pada bank tersebut dapat dikatakan bagus dan nilai maksimum NPL adalah 5.45\%, terdapat pada bank Mutiara tahun 2013 yang menunjukan bahwa NPL pada bank tersebut dapat dikatakan kurang bagus.

Nilai rata-rata NPM 10,42\% dengan standar deviasi 15,264 hal ini menunjukan bahwa rata-rata bank tergolong sehat karena sesuai dengan ketetapan BI pada PBI nomor $3 / 21 / 2001$ yaitu suatu bank dikatakan sehat apabilai rasio NPM nya melebih 4,9\%. Yang berarti rata-rata bank menunjukan performa yang baik dalam menghasilkan laba bersih.Hasil dari standar deviasi NPM menunjukan sebaran data dalam sampel lebih kecil dari mean NPM maka nilai rata-rata merupakan representasi yang buruk dari keseluruhan data, nilai minimum dan maksimum NPM adalah $-82,45 \%$ dan 33,53\%. Dimana nilai terendah dimiliki oleh bank Mutiara pada tahun 2013yang menunjukan bahwa NPM pada bank tersebut dapat dikatakan tidak bagus dan nilai tertinggi dimiliki oleh bank Central Asia pada tahun 2012

Nilai rata-rata ROA $1,4 \%$ dengan standar deviasi 1,849 , dari hasil nilai rata-rata yang di dapat menurut Lestari dan dan Sugiharto (2007:196) angka ROA dapat dikatakan baik apabila lebih kecil dari $2 \%$ dapat dikatakan bahwa rata-rata ROA dari tiap-tiap bank cukup bagus. Hasil penghitungan standar deviasi ROA menunjukan sebaran data dalam sampel lebih besar dari mean ROA maka nilai rata-rata merupakan representasi yang buruk dari keseluruhan data. Nilai minimum ROA adalah $-7,63 \%$ yang terdapat pada bank Mutiara pada tahun 2013 yang menyatakan bahwa ROA pada bank tersebut dapat dikatakan baik dan nilai maksimum ROA adalah 4,46\% terdapat pada bank BRI pada tahun 2013 yang menyatakan bahwa ROA pada bank tersebut dapat dikatakan kurang baik.

Nilai rata-rata LDR 84,79\% dengan standar deviasi 10,136, Menurut ketentuan Bank Indonesia, LDR maksimum bernilai $110 \%$, namun idealnya LDR berkisar antara $75-80 \%$. Semakin kecil LDR berarti bank tersebut kurang menyalurkan kreditnya, sementara bila LDR di atas $110 \%$ akan berakibat menekan CAR. Berdasarkan hasil rata-rata yang didapat menunjukan bahwa rata-rata dari bank tersebut tergolong cukup baik, dan membuktikan bahwa rata-rata bank mampu membayarkan kembali penarikan dana yang dilakukan oleh deposan dengan mengandalkan kredit sebagai sumbernya.standar deviasi LDR menunjukan sebaran data dalam sampel lebih kecil dari mean LDR maka nilai rata-rata dapat digunakan sebagai representasi dari keseluruhan data. Nilai miminum pada LDR adalah 55,78\% yang terdapat pada bank Capital Indonesia pda tahun 2015 hal ini menunjukan bahwa LDR pada bank tersebut kurang baik dan nilai maksimum LDR adalah 113,3\% yang terdapat pada bank QNB Kesawan pada tahun 2013 walau melampaui batas maksimum dari ketentuan Bank Indonesia namun LDR pada bank tersebut masih dapat dikategorikan cukup baik.

Nilai rata-rata IER 5,8\% dengan standar deviasi 2,0956. Standar kriteria oleh Bank Indonesia dinilai sehat jika rasio beban bunga dibawah 5\%. Semakin kecil rasio IER maka semakin kecil tingkat resikonya.standar deviasi IER menunjukan sebaran data dalam sampel lebih kecil dari mean IER maka nilai rata-rata dapat digunakan sebagai representasi dari keseluruhan data Dari hasil rata-rata dalam penghitungan menunjukan 
bahwa IER rata-rata dari 29 bank adalah 5,8\% yang menurut kriteria Bank Indonesia menunjukan performa yang kurang baik dalam mengatasi suatu resiko. Nilai standar deviasi yang di peroleh IER menunjukan bahwa. Nilai minimum dan maksimum IER selama periode 2012-2015 dari 29 bank adalah 0,32\% dan 11,9\%. Dimana IER terendah dimiliki oleh bank Himpunan Saudara 1906 pada tahun 2014 yang menunjukan IER pada bank tersebut bagus dan IER teretinggi dimiliki oleh bank Victoria Internasional pada tahun 2015 yang menunjukan IER pada bank tersebut tidak bagus.

Nilai rata-rata GDP dari tahun 2012-2015 adalah 3544,575 dan standar deviasi sebesar 135,827. Jika diperhatikan GDP selama tahun 2012 mengalami penurunan hingga tahun 2015. Padahal semakin meningkatnya nilai GDP maka mengindikasikan pertumbuhan ekonomi yang baik yang pada akhirnya ada ekspektasi dari perbankan untuk mendapatkan keuntungan yang lebih banyak. Tapi dalam informasi data yang didapatkan pertumbuhan GDP dari tahun 2012-2015 mengalami penurunan. Hal ini dapat berakibat kurang baik terhadap tingkat kesehatan bank. Hasil standar deviasi GDP menunjukan bahwa. Nilai minimum dan maksimum GDP adalah 3700,5 pada tahun 2015 dan 3346,5 pada tahun 2015.

Nilai rata-rata TKS 66,83\%. Dengan standar deviasi 11,365. Berdasarkan Surat Keputusan Direktur Bank Indonesia Nomor 6/23/DPNP tanggal 31 Mei 2004. Suatu bank dikatakan sehat apabilai memiliki nilai kredit sebesar 81-100, cukup sehat 66-81, kurang sehat 51-66 dan tidak sehat 0-51. Dari hasil yang didapat dalam perhitungan rata-rata TKS memiliki nilai 66,83\% yang berarti sesuai dengan Surat Keputusan Direktur Bank Indonesia Nomor 6/23/DPNP tanggal 31 Mei 2004. Suatu bank dapat dikatakan cukup sehat, karena nilai berkisar 61-81. Hasil standar deviasi dalam penghitungan menunjukan bahwa bank . nilai TKS minimum adalah 35\% yang dimiliki oleh bank Mutiara pada tahun 2013 dan nilai TKS maksimum adalah 85,51\% yang dimiliki oleh Bank Central Asia pada tahun 2012.

\section{Pengujian Model Analisis}

Tabel 2. Common Effect Model

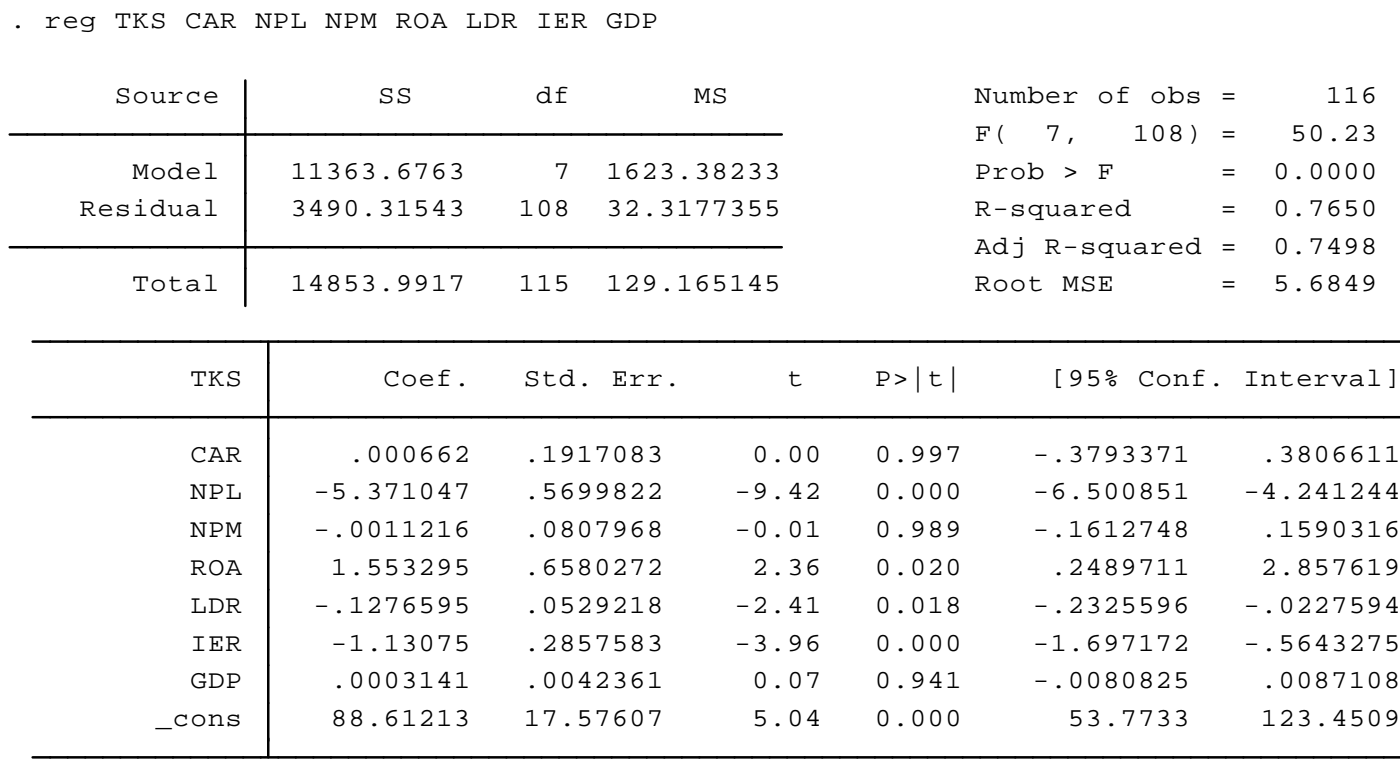

Sumber: Data Diolah Stata 13 
Menggunakan model common effect dari tujuh variabel yang signifikan terhadap TKS terdapat 4 variabel yang signifikan yaitu NPL $(0,000)$, ROA $(0,020)$, LDR $(0,018)$ dan IER $(0,000)$ karena lebih kecil dibandingkan dengan $\alpha=5 \%$. Probabilitas pada model ini lebih kecil dari $\alpha=5 \%$ maka uji $\mathrm{F}$ menerima $\mathrm{H} 1$ pada taraf signifikansi $5 \%$ yang berarti semua variabel independen secara stimultan mempunyai pengaruh yang signifikan pada variabel dependen. Koefisien determinasi $\left(\mathrm{R}^{2}\right)$ untuk model Common Effect ini sebesar $0,7650(76,50 \%)$ yang artinya kemampuan variabel bebas dalam menjelaskan varians dari variabel terikatnya adalah sebesar $76,50 \%$. Berarti terdapat $23.50 \%$ varians variabel terikat yang dijelaskan oleh faktor lain.

Tabel 3. Fixed Effect Model



Sumber: Data Diolah Stata 13

Menggunakan model fixed effect dari tujuh variabel yang signifikan terhadap TKS yaitu NPL dan IER karena lebih kecil dibandingkan dengan $\alpha=5$. Probabilitas pada model ini $>$ dari $\alpha=5 \%$ maka uji $\mathrm{F}$ menerima $\mathrm{H} 1$ pada taraf signifikansi 5\% yang berarti semua variabel independen secara stimultan mempunyai pengaruh yang signifikan pada variabel dependen. Sigma_u sebesar 4,806 menjelaskan bahwa varasi konstan, dalam hal ini berarti perbedaan rata-rata dari rata-rata unit tertentu adalah 4,806. Sedangkan sigma_e sebesar 3,963 menjelaskan variasi efek unit residual. Koefisien determinasi $\left(\mathrm{R}^{2}\right)$ untuk model Common Effect ini sebesar 0,6974 (69,74\%) yang artinya kemampuan variabel bebas dalam menjelaskan varians dari variabel terikatnya adalah sebesar 69,74\%. Berarti terdapat 30,26\% varians variabel terikat yang dijelaskan oleh faktor lain. 
Tabel 4. Random Effect Model

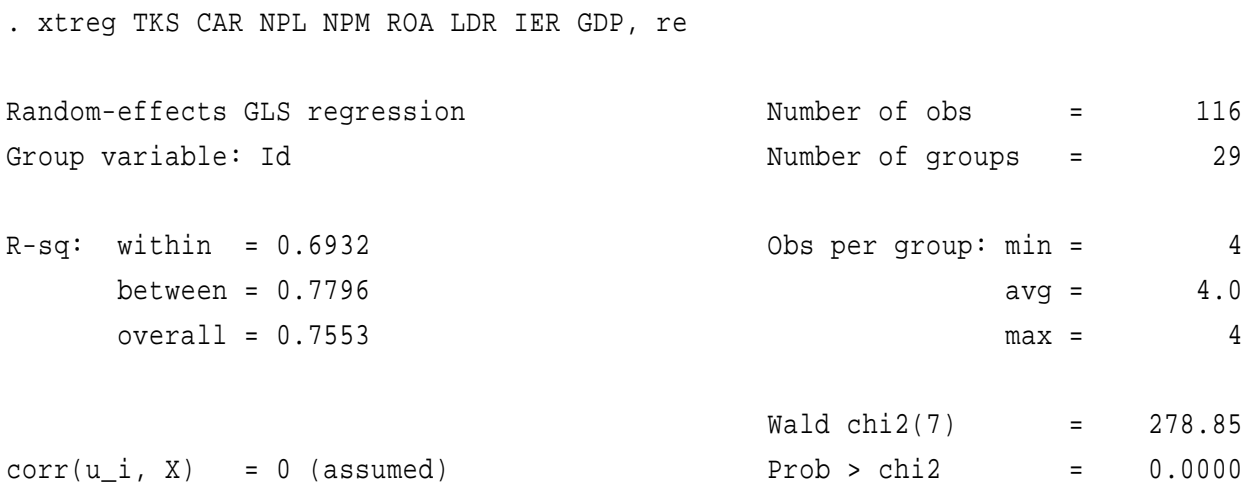

Menggunakan model random effect dari tujuh variabel yang signifikan terhadap TKS yaitu NPL $(0,0000)$ dan IER $(0,000)$ karena lebih kecil dibandingkan dengan $\alpha=5 \%$, Probabilitas pada model ini > dari $\alpha=5 \%$ maka uji $\mathrm{F}$ menerima $\mathrm{H} 1$ pada taraf signifikansi $5 \%$ yang berarti semua variabel independen secara stimultan mempunyai pengaruh yang signifikan pada variabel dependen.Sigma_u sebesar 4,184 menjelaskan bahwa varasi konstan, dalam hal ini berarti perbedaan rata-rata dari rata-rata unit tertentu adalah 4,184. Sedangkan sigma_e sebesar 3,966 menjelaskan variasi efek unit residual. Koefisien determinasi $\left(\mathrm{R}^{2}\right)$ untuk model Common Effect ini sebesar 0,6932 $(69,32 \%)$ yang artinya kemampuan variabel bebas dalam menjelaskan varians dari variabel terikatnya adalah sebesar $69,32 \%$. Berarti terdapat $30,68 \%$ varians variabel terikat yang dijelaskan oleh faktor lain.

\section{Pengujian Pemilihan Model}

a. Uji Chow. Uji Chow yaitu pengujian untuk menentukan model Pooled OLS atau Fixed Effect Model yang paling tepat digunakan dalam mengestimasi data panel untuk penelitian ini.

Tabel 5. Hasil Uji Chow

$\begin{array}{ll}\text { F test that all u_i=0: } \quad F(28,80)=5.07 & \text { Prob }>F=0.0000\end{array}$

Sumber : Data yang diolah

Hipotesis dalam uji chowadalah :

H0: Common Effect Model atau Pooled OLS

H1: Fixed Effect Model

Probabilitasnya 0,0000 lebih kecil dari $\alpha=5 \%$ maka dapat disimpulkan bahwa hipoteis dalam uji chow adalah H1 diterima dan H0 ditolak. Maka kesimpulan dalam uji Chow ini model yang dipilih adalah adalah model fixed effect.

b. Uji Hausman. Uji Hausman digunakan untuk memilih antara metode pendekatan Fixed Effect atau metode Random Effectyang paling tepat digunakan dalam mengestimasi data panel untuk penelitian ini. 
Tabel 6. Hasil Uji Haussman

Chi2 $(6)=(b-B)^{1}\left[\left(V_{-} b-V_{-} B\right)^{\wedge}(-1)\right](b-B)$
$=6,94$

Sumber : Hasil Pengolahan Data

Hipotesis uji hausman adalah sebagai berikut:

$\mathrm{H}_{0}$ : model Random Effect

$\mathrm{H}_{1}$ : Model Fixed Effect.

Probabilitasnya 0,4350 lebih besar dari $\alpha=5 \%$ maka daapt disimpulkan bahwa hipoteis dalam uji hausman adalah $\mathrm{H} 0$ diterima dan $\mathrm{H} 1$ ditolak. Maka hasil kesimpulan dalam uji Hausman ini adalah model Random effect.

c. Uji Lagrange Multiplier. Uji yang dilakukan untuk mengetahui apakah model Random Effect atau model Common Effect (OLS) yang paling tepat digunakan.

Tabel 7. Hasil Uji Lagrange Multiplier

\begin{tabular}{c}
\hline Chibar2 $(1)=36,97$ \\
\hline Prob $>$ Chibar2 $=0,0000$ \\
\hline Sumber : Hasil Pengolahan Data
\end{tabular}

Hipotesis uji Lagrange Multiplier:

H0: modelCommon Effect atauPooled OLS

H1: Model Random Effect

Probabilitasnya 0,0000 lebih kecil dari $\alpha=5 \%$ maka daapt disimpulkan bahwa hipoteis dalam uji langrange adalah $\mathrm{H} 1$ diterima dan $\mathrm{H} 0$ ditolak, Maka hasil kesimpulan dalam uji Lagrange adalah model random effetct. Jadi setelah melakukan 3 pengujian yaitu uji Chow, uji Hasuman dan uji Lagrange di dapat kesimpulan model yang cocok untuk penelitian ini yaitu model random effect.

Uji Asumsi Klasik Multikolinearitas. Multikolinearitas merupakan suatu situasi dimana beberapa atau semua variabel bebas berkorelasi kuat.

Tabel 8. Hasil Uji Multikolinearitas

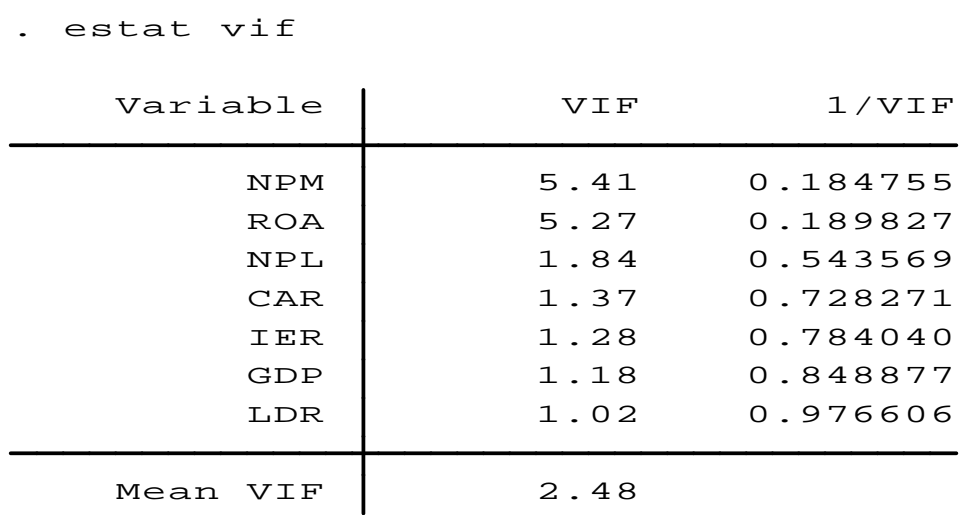


Sumber: Data yang diolah

Nilai VIF dan $1 /$ VIF di atas, apabila $\mathrm{VIF}<10$ dan $1 / \mathrm{VIF}>0,1$, dari data di atas nilai VIF pada tiap masing-masing variabel tidak ada yang melebih 10, dan nilai 1/VIF pada tiap masing-masing variabel lebih dari 0,1 maka dapat dikatakan bahwa model regresi lienar berganda bebas gejala multikolinearitas.

Koefisien Determinasi. Hasil dari pemilihan model bahwa Random Effect lebih baik untuk penelitian ini, maka didapat pula nilai R Squarenya 0,6932 $(69,32 \%)$ yang artinya kemampuan variabel bebas dalam menjelaskan varians dari variabel terikatnya adalah sebesar $69,32 \%$. Berarti terdapat 30,68\% varians variabel terikat yang dijelaskan oleh faktor lain.

Uji t . Uji signifikansi t test masing-masing variabel dapat diuraikan sebagai berikut :

1. Pengaruh Variabel CAR terhadap Tingkat Kesehatan Bank. Dari hasil penelitian diperoleh variabel CAR memiliki nilai signifikan sebesar 0,679 lebih besar dari 0.05, dan koefisiennya 0,742 maka hipotesis $1(\mathrm{H} 1)$ berbunyi "Tidak terdapat pengaruh pada variabel CARterhadap tingkat kesehatan bank" ditolak.

2. Pengaruh Variabel NPL terhadap Tingkat Kesehatan Bank. Dari hasil penelitian diperoleh variabel NPL memiliki nilai signifikan sebesar 0,000 lebih kecil dari 0.05, dan koefisien nya $-5,260$, maka hipotesis 2 (H2) berbunyi "Terdapat pengaruh yang signifikan pada variabel NPLterhadap tingkat kesehatan bank". Diterima.

3. Pengaruh Variabel NPM terhadap Tingkat Kesehatan Bank. Dari hasil penelitian diperloeh variabel NPM memiliki nilai signifikan sebesar 0,651 lebih besar dari 0,05 dan koefisien nya 0,333, maka hipotesis 3 (H3) berbunyi "Tidak terdapat pengaruh yang signifikan pada variabel NPMterhadap tingkat kesehatan bank". Ditolak.

4. Pengaruh Variabel ROA terhadap Tingkat Kesehatan Bank. Dari hasil penelitian diperloeh variabel ROA memiliki nilai signifikan sebesar 0,131 lebih besar dari 0,05 dan koeifsiennya 0,850 maka hipotesis $4(\mathrm{H} 4)$ berbunyi "Tidak terdapat pengaruh yang signifikan pada variabel ROAterhadap tingkat kesehatan bank" ditolak.

5. Pengaruh Variabel LDR terhadap Tingkat Kesehatan Bank. Dari hasil penelitian diperloeh variabel LDR memiliki nilai signifikan sebesar 0,053 lebih kecil dari atau sama dengan 0,05 dan koefisiennya -0,124, maka hipotesis 5 (H5) berbunyi "Tidak terdapat pengaruh yang signifikan pada variabel LDRterhadap tingkat kesehatan bank"ditolak.

6. Pengaruh Variabel IER terhadap Tingkat Kesehatan Bank. Dari hasil penelitian diperloeh variabel IER memiliki nilai signifikan sebesar 0,010 lebih kecil dari 0,05 dan koefisiennya $-0,708$, maka hipotesis 6 (H6) berbunyi "Terdapat pengaruh yang signifikan pada variabel IERterhadap tingkat kesehatan bank".Diterima

7. Pengaruh Variabel GDP Perkapita terhadap Tingkat Kesehatan Bank. Dari hasil penelitian diperloeh variabel GDP Perkapita memiliki nilai signifikan sebesar 0,429 lebih besar dari 0,05 dan koefisiennya 0,003 maka hipotesis 7 (H7) berbunyi "tidak Terdapat pengaruh yang signifikan pada variabel GDP Perkapita terhadap tingkat kesehatan bank"ditolak.

Uji F. Dari hasil perhitungan diperoleh nilai p-valuesebesar 0,0000 hal ini berarti signifikan karena lebih kecil dari tingkat kepercayaan 5\% yang menunjukan hasil uji ini menolak $\mathrm{H} 0$ dan menerima H1.yang berarti dari hasil uji $\mathrm{F}$ ini dapat disimpulkan bahwa variabel CAR, NPL, NPM, ROA, LDR, dan IER secara bersama-sama mempunyai 
pengaruh terhadap tingkat kesehatan bank Dari hasil uji $\mathrm{F}$ ini dapat disimpulkan bahwa variabel CAR, NPL, NPM, ROA, LDR,IER, GDP perkapita secara bersama-sama mempunyai pengaruh terhadap tingkat kesehatan bank dan dapat disimpulkan bahwa model dalam penelitian ini layak untuk diteliti.

Analisis Penliaian Tingkat Kesehatan Bank. Penilaian kesehatan bank diukur dengan faktor permodalan, kualitas aktiva produktif, manajemen, earnings, likuiditas, sensitifitas resiko pasar dan GDP Perkapita dimana penilaian tersebut dilakukan dengan mengkialifikasikan komponen dari masing-masing faktor, kemudian diberi bobot sesuai dengan Peraturan Bank Indonesia Nomor 6/10/PBI/2004 Tanggal 12 April 2004 dimana bobot untuk permodalan sebesar $25 \%$, bobot kualitas aktiva produktif $30 \%$, bobot untuk manajemen sebesar $20 \%$, bobot untuk earnings sebesar $10 \%$, bobot untuk likuiditas sebesar $10 \%$ dan bobot untuk sensititas resiko pasar sebesar 5\%, yang dimana dinyatakan dalam nilai kredit 0 sampai dengan maksimal 100. Cara penghitungan selengkapnya dapat dilihat pada lampiran 6 .

Setelah menghitung berdasarkan nilai kredit dari faktor yang dinilai maka didapat predikat hasil penelitian tingkat kesehatan yang menetapkan empat golongan tingkat kesehatan bank dimulai dari prediakat sehat, cukup sehat, kurang sehat dan tidak sehat.

Sesuai dengan Surat Keputusan Direktur Bank Indonesia Nomor 6/23/DPNP tanggal 31 Mei 2004 jika nilai 81-100 di katakan sehat.Berdasarkan hasil penghitungan untuk masing-masing indikator dari CAMELS selama periode 2012-2015 maka telah menghasilkan predikat sesuai dengan Surat Keputusan Direktur Bank Indonesia Nomor 6/23/DPNP tanggal 31 Mei 2004

Penghitungan penentuan Tingkat Kesehatan Bank:

1. Cara penghitungan nilai kredit faktor permodalan (CAR) untuk bank BRI Argoniaga

Penghitungan nilai kredit CAR tahun 2012

Rasio CAR $=14,8 \%$

Nilai Kredit $(\mathrm{NK})=\frac{\text { rasio }}{0,1 \%}+\mathbf{1}$

$$
\begin{aligned}
& \frac{14,8 \%}{0,1 \%}+1 \\
= & 149(\text { maksimal } 100)
\end{aligned}
$$

Penghitungan nilai bobot CAR tahun 2012

Nilai Bobot $\quad=100 \times 25 \%$

$$
=25
$$

2. Cara penghitungan faktor kualitas aktiva produktif (NPL) untuk bank BRI Argoniaga

Penghitungan nilai kredit NPL tahun 2012

Rasio NPL $=1,56 \%$

Nilai Kredit $(\mathrm{NK})=\frac{5 \%-\text { rasio }}{0.1 \%} \times 2$

$$
\begin{aligned}
& \frac{5 \%-1,56 \%}{0,1 \%} \times 2 \\
= & 68,8
\end{aligned}
$$

Penghitungan nilai bobot untuk NPL tahun 2012 
Nilai Bobot $\quad=68,8 \times 30 \%$

$$
=20,64
$$

3. Cara penghitungan faktor manajemen (NPM) untuk bank BRI Argoniaga

Penghitungan nilai kredit NPM tahun 2012

Rasio NPM $=9,56 \%$

Nilai Kredit $(\mathrm{NK})=$ Nilai rasio NPM

$$
=9,56 \%
$$

Penghitungan nilai bobot untuk NPM tahun 2012

Nilai Bobot $=9,56 \times 20 \%$

$$
=1,91
$$

4. Cara penghitungan faktor earnings (ROA) untuk bank BRI Argoniaga

Penghitungan nilai kredit ROA tahun 2012

Rasio ROA $=1,27 \%$

Nilai Kredit $(\mathrm{NK})=\frac{\text { Rasio }}{\mathbf{0 , 0 1 5} \%}+\mathbf{1}$

$$
\begin{aligned}
& \frac{1,27 \%}{0,015 \%}+\mathbf{1} \\
= & 85,67
\end{aligned}
$$

Penghitungan nilai bobot untuk ROA tahun 2012

Nilai Bobot $=85,67 \times 10 \%$

$$
=8,57
$$

5. Cara penghitungan faktor likuiditas (LDR) untuk bank BRI Argoniaga

Penghitungan nilai kredit LDR tahun 2012

Rasio LDR $=82,84 \%$

Nilai Kredit $(\mathrm{NK})=$ Rasio LDR $<110 \%$ nilai kredit 100

$$
=100
$$

Penghitungan nilai bobot untuk LDR tahun 2012

Nilai Bobot $=100 \times 10 \%$

$$
=10
$$

6. Cara penghitungan faktor sensitifitas resiko pasar (IER) untuk bank BRI

Argoniaga

Penghitungan nilai kredit IER tahun 2012

Rasio IER = $=3,93 \%$

Nilai Kredit $(\mathrm{NK})=$ IER $\geq 5 \%$ nilai kreditnya adalah 100

$$
=100
$$

Penghitungan nilai bobot untuk IER tahun 2012

Nilai Bobot $\quad=100 \times 5 \%$

$$
=5
$$

Jumlah nilai bobot BRI Argoniaga tahun 2012

$=25+20,64+1,91+8,57+10+5$

$=71,12$ (Cukup Sehat)

Pembahasan. Pengaruh CAR terhadap tingkat kesehatan bank. Penelitian ini sesuai dengan penelitian milik Titik Aryati dan Shirin Balafifi (2007) yang menunjukan bahwa CAR tidak memiiki pengaruh yang signifikan terhadap tingkat kesehatan bank, akan tetapi hasil penelitian ini bertolak belakang dengan penelitian milik Luciana Spica Almilia dan 
Winny Herdiningtyas (2005) yang menyatakan bahwa rasio CAR mempunyai pengaruh yang signifikan terhadap kesehatan bank.

Tidak ditemukannya pengaruh yang signifikan antara CAR dengan tingkat kesehatan bank karena secara keseluruhan bank telah memenuhi batas minimal CAR yang telah ditentukan oleh Bank Indonesia sebesar 8\%. Hal ini ditunjukan dengan hasil statistik deskriptif yakni nilai minimum dari CAR untuk keseluruhan bank sebesar 8,02\%

Pengaruh NPL terhadap tingkat kesehatan bank. Dari hasil analisis dari hipotesis kedua menyatakan bahwa NPL berpengaruh signifikan terhadap tingkat kesehatan bank dikarenakan nilai signifikan NPL lebih kecil dari $\alpha=5 \%$, sehingga hipotesis dapat diterima. Yang berarti menunjukan adanya pengaruh NPL terhadap kesehatan bank dimana bank mampu mengelola kreditnya dengan baik dalam memberikan kredit kepada masyarakat maupun dalam pengembalian kreditnya sesuai dengan syarat dan ketentuan yangberlaku sehingga tidak menimbulkan kredit bermasalah dan dalam hal ini dapat dibilang bahwa tingkat kesehatan bank terhadap kredit bank cukup baik. Namun pernyataan ini tidak sejalan dengan penelitian milik (Almilia dan Herdiningtyas:2005) yang menyatakan NPL tidak mempunyai pengaruh terhadap kondisi perbankan. NPL yang signifikan dikarenakan telah memenuhi batas malsimal NPL sebesar 5\%. Hal ini dapat dibuktikan dengan nilai mean NPL sebesar $1,43 \%$

Dengan koefisiennya yang negatif dimana adanya hubungan yang searah dengan tingkat kesehatan bank, artinya tiap kenaikan $1 \%$ maka tingkat kesehatan bank akan turun sebesar 5,260\%. Demikian sebaliknya jika NPL turun sebesar $1 \%$ maka akan mengakibatkan tingkat kesehatan bank naik sebesar 5,260\%. Dengan asumsi bahwa variabel bebasnya konstan. Nilai koefisien negatif dikarenakan jumlah kredit yang diberikan relatif rendah sedangkan dana yang dihimpun bank tinggi yang menyebabkan biaya bunga yang ditanggung relatif lebih tinggi dari pendapatan bunga sehingga probabilitas bank mengalami kebangkrutan menjadi tinggi.

Pengaruh NPM terhadap tingkat kesehatan bank. Komponen manajemen yang diukur atau diwakili dengan menggunakan rasio NPM tidak berpengaruh signifikan terhadap tingkat kesehatan bank dikarenakan nilai signifikan NPM lebih besar dari 0,05, sehingga hipotesis ditolak, hal ini berarti bahwa bank kurang memiliki kemampuan dalam memperoleh pendapatan pada tingkatan operasionalnya. NPM ditolak karena Penelitian ini tidak sejalan dengan penelitian milik (Fadah:2009) yang dalam hasil penelitiannya menyatakan bahwa NPM berpengaruh signifikan terhadap kebangkrutan bank.

Koefisien NPM bernilai positif yang menunjukan bahwa adanya hubungan searah antara variabel NPM dengan tingkat kesehatan bank yang artinya setiap kenaikan NPM sebesar $1 \%$ maka akan meningkatkan tingkat kesehatan bank sebesar 0,333\%, dengan asumsi bahwa variabel bebas lainnya konstan.

Pengaruh ROA terhadap tingkat kesehatan bank. Komponen earnings yang diukur atau diwakili dengan menggunakan rasio ROA tidak berpengaruh signifikan terhadap tingkat kesehatan bank dikarenakan nilai signifikan ROA lebih besar dari 0,05, sehingga hipotesis ditolak, yang berarti hal ini menunjukan tidak adanya pengaruh ROA terhadap kesehatan suatu bank. Hal ini disebabkan karena kurangnya kemmapuan bank dalam meghasilkan laba bersih serta nilai minimum data yang tidak bangkrut lebih kecil dari nilai maksimum data yang bangrkut. Hasil penelitian ini sejalan dengan penelitian milik 
(Almilia dan Herdiningtyas:2005) dan (Vidyarto Nugroho:2012) yang menyatakan ROA tidak mempunyai pengaruh terhadap kondisiperbankan. Namun penelitian ini sejalan dengan penelitian milik (yayukusdiana:2014) yang menyatakan bahwa ROA berpenagruh signifikan terhadap kondisi berbankan.

Nilai koefisien yang positif artinya secara parsial rasio ROA berpengaruh signifikan terhadap tingkat kesehatan bank. dimana nilai koefisiennya positif yang menunjukan bahwa adanya hubungan searah antara variabel ROA dengan tingkat kesehatan bank yang artinya setiap kenaikan ROA sebesar 1\% maka akan meningkatkan tingkat kesehatan bank sebesar $0,850 \%$, begitu juga sebaliknya, dengan asumsi bahwa variabel bebas lainnya konstan.

Pengaruh LDR terhadap tingkat kesehatan bank. Variabel likuiditas yang diukur dengan menggunakan rasio LDR tidak berpengaruh signifikan terhadap tingkat kesehatan bank dengan nilai 0,1,41 dikarenakan nilai signifikan LDR lebih besar atau sama dengan $\alpha=5 \%$, sehingga hipotesis dapat diterimayang berarti hal ini menunjukan tidak adanya pengaruh LDR terhadap kesehatan suatu bank dimana bank tersebut tidak atau kurang mampu menunjukkanseberapa jauh kemampuan bank dalam membayar kembali penarikan dana yang dilakukan deposan dengan mengandalkan kredit yang diberikan sebagai sumber. Hasil penelitian tidak sejalan dengan hasil penelitian milik (Suharman:2007) bahwa LDR berpengaruh signifikan terhadap tingkat kesehatan bank. Namun penelitian ini sejalan dengan penelitian milik (Sumantri dan Teddy:2010) dimana dalam penelitiannya memanfaatkan rasio keuangan dalam memprediksi kepailitan Bank Nasional menunjukan hasil bahwa rasio CAR, NPL dan BOPO tidak mempiliki pengaruh yang signifikan terhadap kepailitan bank sedangkan rasio ROA dan LDR memiliki pengaruh yang signifikan terhadap kelapilitan bank.

LDR yang berpengaruh negatif hal ini disebabkan karena kemampuan bank dalam memasarkan dana belum maksimal sehingga bank menginvestasikan dana yang dihimpun dalam bentuk aktiva produktif lain yang tidak beresiko. Hal ini dapat dilihat pada nilai rata-rata LDR sebesar $84,79 \%$ yang mengindikasikan bahwa rata-rata bank memiliki kemampuan untuk memasarkan dana yang dimilikinya meskipun belum dilakukan secara maksimal yang menyebabkan biaya bunga yang ditanggung relatif lebih tinggi dari pendapatan bunga sehingga profitabilitas bank mengalami kebangkrutan menjadi lebih tinggi, disamping itu nilai rata-rata NPL 1,43\% yang menunjukan bahwa rata-rata kredit yang diberikan tiak mengalami masalah dalam pengembaliannya sehingga profitabilitas bank mengalami kebankrutan menjadi rendah.

Pengaruh IER terhadap tingkat kesehatan bank. Variabel sesitifitas resiko pasar yang diukur dengan menggunakan rasio IER berpengaruh signifikan terhadap tingkat kesehatan bank dikarenakan nilai signifikan IER lebih kecil dari 0,05, sehingga hipotesis dapat diterima yang berarti hal ini menunjukan adanya pengaruh IER terhadap kesehatan suatu bank dimana bank tersebut mampu mengukur seberapa besar tingkat sensitivitas suatu bank terhadap resiko pasar yang terjadi.Pengaruh yang signifikan dikarenakan bank mampu menutupi kerugian karena adanya fluktuasi suku bunga dan nilai tukar yang ada pada saat ini. Koefisien yang bernilai negatif artinya adanya hubungan yang berlawanan arah dengan tingkat kesehatan bank, artinya tiap kenaikan $1 \%$ maka akan menurunkan tingkat kesehatan bank sebesar 1,538\%. Demikian sebaliknya jika IER turun sebesar 1\% 
maka akan mengakibatkan tingkat kesehatan bank naik sebesar 1,538\%. Dengan asumsi bahwa variabel bebasnya konstan.

Pengaruh GDP terhadap tingkat kesehatan bank. Tidak berpengaruhnya GDP terhadap tingkat kesehatan bank. Hal inidikarenakan karena pendapatan yang dimiliki rakyat lebih memilih digunakan untuk berbelanja dan memenuhi kebutuhan pokoknya dari pada ditabung di bank. Analsisi dilanjutkan pada penetapan kesimpulan predikat tingkat kesehatan bank yaitu terdapat setidaknya sekitar lebih dari $50 \%$ bank selama periode 2012-2015 dalam keadaan cukup sehat dan ada beberapa bank yang selama periode tersebut mengalami peningkatan dan penurunan, bahkan ada bank yang tetap berada pada predikat yang tidak sehat selama 4 periode.

\section{PENUTUP}

Kesimpulan penelitian ini, emnemukan bahwa hanya terdapat dua variabel yang signifikan yaitu Variabel NPL dan IER. Predikat kinerja bank selama periode 2012-2015 dengan menggunakan metode CAMELS diketahui setidaknya terdapat lebih dari setengahnya yang menunjukan bahwa kondisi bank tersebut cukup stabil. Artinya bank tersebut dapat dikategorikan cukup sehat. Akan tetapi ada beberapa bank yang mengalami peningkatan dan penurunan selama tahun 2012 hingga tahun 2015. Bahkan ada bank yang tetap pada predikat tidak sehat selama 4 periode.

\section{DAFTAR RUJUKAN}

Achmad, T, Kusno. (2003). "Analisis Rasio-Rasio Keuangan sebagai Indikator dalam Memprediksi Potensi Kebangkrutan Perbankan Indonesia". Edia Ekonomi dan Bisnis, XV (1), 54-75.

Almilia, Luciana Spica dan Winny Herdiningtyas. (2005). "Analisis Rasio CAMEL terhadap Prediksi Kondisi Bermasalah pada Lembaga Perbankan Periode 20002002". Jurnal Akuntansi dan Keuangan, Fakultas Ekonomi Universitas Kristen Petra.7 (2).

Bank Indonesia, (2004). Surat Edaran Bank Indonesia No.13/24/DPNP Tentang Tata Cara Penilaian Tingkat Kesehatan Bank Umum.25 Oktober 2011. , (2004). Surat Edaran Bank Indonesia No. 6/23/DPNP Perihal Sistem Penilaian Tingkat Kesehatan Bank Umum. Jakarta.31 Mei 2004 , (2004). Peraturan Bank Indonesia No.6/10/PBI/2004 Tentang Sistem Penilaian Tingkat Kesehatan Bank Umum. 12 April 2004. , (2004). Surat Edaran Bank Indonesia No.14/37/DPNP Tentang Tata Cara Penilaian Tingkat Kesehatan Bank Umum.27 Desember 2012. , (2001). Ketetapan Bank Indonesia pada Peraturan Bank Indoneisa No. 3/21/2001 Tentang Tata Cara Penilaian Tingkat Kesehatan Bank Umum.

Budisantoso, Totok, Triandaru Sigit. (2006). Bank dan Lembaga Keuangan Lain. Jakarta :Salemba Empat.

Dendawijaya, Lukman. (2009). Manajemen Perbankan. Edisi Kedua. Cetakan Kedua. Ghalia Indonesia.

Ismail. (2009). Akuntansi Bank: Teori dan Aplikasi dalam Rupiah. Jakarta: Kencana 2011. Kasmir, MM. (2008). Analisis Laporan Keuangan, edisi pertama, cetakan pertama, Jakarta : Rajawali Pers. 
Lestari, Maharani Ika dan Toto Sugiharto. (2007). "Kinerja Bank Devisa Dan Bank Non Devisa Dan Faktor-faktor Yang Mempengaruhinya". Proceeding PESAT (Psikologi, Ekonomi, Sastra, Arsitek \& Sipil), 21-22 Agustus, Vol.2. Fakultas Ekonomi, Universitas Gundarama.

Nugroho, Vidyarto. (2012). Pengaruh CAMEL Dalam Memprediksi Kebangkrutan Bank. Jurnal Akuntansi. XVI (1), 145-161.

Setyawati, Indah dan Marita. (2010). "Evaluasi Kinerja Model CAMELS Pada PT Bank Danamon Indonesia". Kajian Akuntansi, 5 (1).

Situs Resmi Bursa Efek indonesia. 2016. http://www.idx.co.id

Situs Resmi World Bank. 2016. www.worldbank.org/

Suharman,H. (2007). “Analisis Risiko Keuangan untuk Memprediksi Tingkat Kegagalan Usaha Bank". Jurnal Ilmiah ASET, 9 (1). Februari.

Sumantri dan Teddy Jurnali. (2010). "Manfaat Rasio Keuangan dalam Memprediksi Kepailitan Bank Nasional". Jurnalistik Bisnis dan Akuntansi, 12 (1), April.

Titik Aryanti dan Shirin Balafif. (2007). "Analisis Faktor yang Mempengaruhi Tingkat Kesehatan Bank Dengan Regresi Logit". Journal the Winner, 8 (2)

Undang -Undang Nomor 4 Tahun 2008 tentang Perbankan. 